\title{
DISCUSSION.
}

\section{EMPIRE AND SUBJECT RACES.•}

I sHould first say a few words on the nature ard aims of this Conference. We are not debating whether there ought to be any subject races or ruling races. We accept the facts. Much less are we meeting to attack the Government. I will tell you what the Conference reminds me of. Two friends of mine who are Governors of large provinces in the East, one in Beluchistan and one in New Guinea, both happen to have told me of a custom they have introduced in order to get better into touch with their subjects. The Governor, every Sunday morning, goes on to his veranda and sits in an easy chair reading a newspaper. If necessary he pretends to go to sleep. No officials are anywhere near him. And then any natives who have anything special to say, any unexplained trouble about which they feel shy or puzzled, come to the veranda and talk to him.

I do not pretend to carry the analogy very far. But our object is, in some rough way, to try and hear from members of various subject races and oppressed nationalities, especially those who are not allowed to speak in their own countries, something of what they suffer and what they desire, and what they have to say in criticism of their governments.

Now in these questions we English occupy a special position. In most cases, though not all, it is we ourselves who are the governing race, the heroes or the villains of the piece. That is to say, for this particular occasion we must regard our Empire in a spirit of self-criticism, not in a spirit of glorification. We come to hear grievances, to consider what errors we have committed, to think of mending the faulty points of our Empire, not of boasting and rejoicing in the good points. It will be said, I know, that as far as the speakers at this conference go, that is what they are always doing; they are always attacking the Empire and never praising it. As to that, I will only say that, if people in general were a little more ready to be occasionally and moderately critical, then we should not have to be incessantly and wearisomely so.

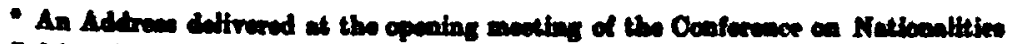

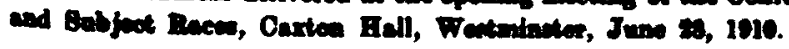


If this nation is to do its work well, some self-criticism is absolutely necessary. We must not cavil, we must not be ungenerous to the errors of men, often great men, hard-pressed in difficult places. But if a spirit of excessive criticism is dangerous to an empire, I think any study of history will show us that empires are subject to another disease, fully as dangerous and a thousand times more common, the disease of violence and vain-glory, the disease of always siding with your own friends and preferring national pride to justice.

If you consider the work done in the world by any Imperial Power such as ourselves, you will of course find both good and evil. First, we generally establish peace, strong government, and social order: the first fundamental goods, on which all social progress must be based. Next, when in contact with lower races, we generally try to educate them, however scrappily and imperfectly, towards higher standards. If we fail to do that we fail in everything. I am not forgetting the dangers and the failures of this process; but allowing for all that, I venture to suggest that if, from the great story of human progress, you were to blot out all that has come to various peoples from contact-and compuisory contact-with higher races than their own, the remainder would be rather a miserable affair.

That is one side of the question. There is also the other. I think we may safely say, and all but the most case-hardened commercial imperialists will agree with us, that if you were, at almost any time in the last few centuries, to search through the world for the greatest crimes and the greatest miseries inflicted by man upon man, you would find them in the peoples, especially the weakest and lowest peoples, who are being governed or exploited by alien powers. The contact of a high civilization with a low is always a danger-point to humanity. [If any one thinks I speak too strongly here, I recommend him to study the history of the treatment of the blacks in Australia, in the New Hebrides, in the Congo territory, in the Cameroons, of the slaves in old days in the West Indies.]

The problem before us is, how two races, the one ruling and the other subject, can live together with advantage to both, each getting as far as possible good from the other and not injury. The problem varies, of course, in every single case. Notably it varies according to the extent of the gulf between the two races. The gulf between an Englishman and a Polynesian or a Negro is enormous : that between an Englishman and an Irishman, between a German and a Pole, is practically non-existent. Between a Russian and a Finn-well, I do not wish to-night to speak of that great crime against civilization, but if Russia is to be judged by its Government, it is easy to see there that the stronger power is on the lower side of the gulf and not on the higher. Our relations 
with the ancient civilizations of the East occupy an intermediate position of special difficulty.

Now, roughly speaking, the great sources of trouble are three : first and chief, even with the best intentions in the world, there is the ordinary lack of mutual understanding ; secondly, there is commercial exploitation, when we try to make money out of our subjects instead of protecting them; thirdly, there is a feeling of rivalry and jealousy between subject and ruler. In dealing with the lowest races this feeling of rivalry does not come in at all, whereas lack of mutual understanding is almost inevitable.

I have been reading lately the White Book of the Territory of Papua, i.e., the annual report made to the Australian Commonwealth Government. It is an admirable government, and the traders are few and well under control. As you read the report of one local magistrate after another you feel that they are all acting as true Пopmeres $\lambda_{a}$ iv, 'shepherds of their people,' always helping, tending, protecting, not destroying and exploiting and identifying civilization with the newest form of rifle. Yet in the midst of this understanding and sympathetic atmosphere, one comes again and again across the complaint "It is impossible to understand the workings of the native mind." I will give one instance. A native had confessed to a cannibal murder. Capital punishment has been abolished for such offences by the present Governor. The man was imprisoned for three years. And after two years in prison, it turned out that the man had not had anything whatever to do with the murder. He was asked why he had confessed; and it appeared that he had confessed because he thought it was expected of him ! As far as one can make out, it was just a case of the extreme suggestibility common in savages. But we came there within an ace of hanging an innocent man, and, if we had, his relations would have resented it.

As a second instance, let me read you a paseage from a letter about the state of the natives in another territory, also one presided over by a peculiarly able and sympathetic Governor. I give no names as I have not the express permission of the official who wrote me the letter.

The abeorption has been going on for ten yourn. What of the alswedy abeorted?

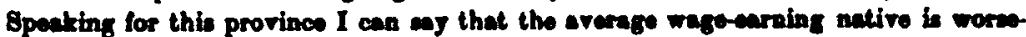

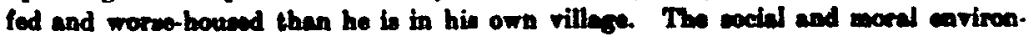

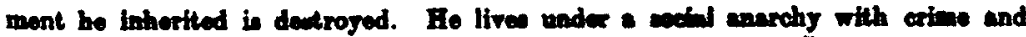

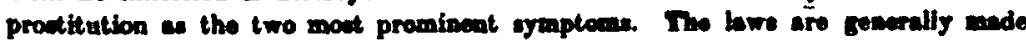
for his mector and dways work for his mactes'n advantege. I an pware of the aforte of the Provineial Commiamion. What chence in thare of that frutt of knowledge over being nad?

In Europe for genorationa we have been making lawa for the wortern with hande. Eere, though citivenahip to on impoenibility for the morter, and a wide 
gulf of rece hinders almot every spark of kindly compreheneion, law, and edminittration more than law, gives no protection. Flwowhere a man is encouraged to live by a fow scres of his own, here no amall presoure in und to make him leave his own land to work tor the large landowner, often an aboentec. And wo throutgh the cale of his life. The mout corious fact in the country to mo is that with fow exceptions the natives do not beliove that wo are bere for their edventege. The millione Britain has spent for then they don't know of. Thes bare enen the opending, but to their mind it is apent for others. Every government intitution that comes clow to them, the tax, the roed paes, the road making, the promerero to

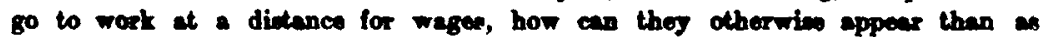
exactione? . . . . I I treated the other day a native who had loct the fingers of his right hand in a mairo-mill-there have been two is fact this leat month. I

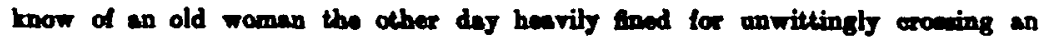
anmarked quarantine boundary with cattle. Anj of as conld give dowem of caneer like these.

That is the dark side of what is generally regarded as a most successful and beneficial government. The trouble there is chiefly due to the commercial exploitation of the country. And that is very often the case. As officials and governors we generally send men of high ability and high principle. We send on the whole the best men we possess. The danger of real cruelty comes not from the officials, but from the traders and adventurers and the broken men who hang upon the skirts of civilization, driven always on by the absentee master of the traders, the unconscious but evergrasping shareholder.

If these evils can be kept down, if we keep public opinion in England always awake, and insist that English opinion, not local opinion, must always be the ultimate judge, if we send good men as officials, pay them well and do not leave them tou long a prey to fever and tropical irritation, and if further we keep a firm hand upon all traders and adventurers who are trying to make fortunes out of the rative, we ought on the whole to be able to make governments of this kind into bright spots and not dark in the general history of humanity.

I have spoken at some length about these lowest races, because they need always to be thought of, and they cannot speak for themselves. We are going to-night to hear about a very different kind of problem, namely our relations as a government with the old and high civilizations of the east, Egypt and India.

The worst things that occur in India seem to be due to the survival of methods of bad government dating from before our time, and no doubt allowed to continue by our lack of thorough understanding and lack of power. I mean such things as the occasional corruption of the police and their use of torture. Other bad things, not in their intention but in their consequences, are the almost inevitable results of planting a highly expensive western 
government upon a people with a much lower standard of expenditure.

The present state of strain and alienation which has arisen between our Government and many of the most progressive minds of India is a deplorable thing, and one which calls for the utmost exercise of thought and patience. One thing chiefly is clear to me. On both sides of this quarrel we have able men, honest and highminded men. We have certainly given of our very best to the government of India. I believe that India has given of her best to movements of the sort in which Mr. Lajpat Rai is a leader. (l may mention that a high official who approved of Mr. Lajpat Rai's deportation told me that there were few men in India for whom he had a greater respect.)

If we are to attain any result at all from these conferences we must all rid ourselves of many evil memories. Or if we remember the facts, we must rid ourselves of the passions and resentments that form round them. Both sides have something to forgive.

And one word more. If ever it were my fate to administer a Press Law, and put men in prison for the books they write and the opinions they stir up among their countrymen, I should not like it, but I should know where to begin. I should first of all lock up my old friend Rudyard Kipling, because in several stories he has used his great powers to stir up in the minds of hundreds of thousands of Englishmen a blind and savage contempt for the Bengali. And many Bengalis naturally have read these stories. You cannot cherish a savage contempt for anyone without its being quickly reciprocated. And when both sides regard each other with the same savage contempt, it is not likely that they can dwell together in peace. And in case Mr. Kipling should feel lonely in his cell, I would send him a delightful companion, Mr. Anstey of Punch. Year after year, clever natives of India come over to England at great sacrifice of money and trouble, to study in our Lniversities and satisfy our tests for obtaining positions in their own country. They compete with us well, and with all the odds against them. And year after year they have found in our greatest weekly newspaper caricatures of themselves-ridiculous Baboos, cowardly, vain, untruthful, in every way absurd, talking bad and bombastic English (not nearly so correct, I suppose, as Mr Anstey's Hindustani), held up for the amusement of the public. Now if these men are to be in any sense our subjects, that sort of thing is not fair play. It is not fair play, and it is not decent policy. If you must insult somebody, insult one who is free and can hit you back. If you want to govern a man, and to have him a loyal and friendly citizen-well, you must give up that luxury. You cannot govern the man and insult him too. This incessant girding at 
the Bengali, the most intellectual and progressive of the peoples of India, has an ugly look. It goes along with much irritable hostility to the Congress, to the students, to almost every Indian society that professes high aims-such, for instance, as the Arya Somaj. There is in such sneers something perilously like jealousy. And if ever in a ruling race there creeps in a tendency to be jealous of its subjects, to dislike them for their good qualities rather than their bad, to keep them out of power not because they are unfit for power, but because they are too obviously fit; such a tendency is, I believe, disastrous to any empire, and the individuals and parties who foster and inflame it have forfeited their claim to stand among the great leaders and governors of the world.

Gilbert MurRay. 